\title{
DETERMINATION OF THE HERBICIDE BASAGRAN RESIDUES IN MAIZE PLANTS AND SOIL
}

\author{
Rehab Edarous Mohamed El-Said Salem \\ Plant Protection Dept., Faculty of Agric., Zagazig Univ., Egypt.
}

\begin{abstract}
The residual effect of bentazone (Basagran 48\% WP) alone and in mixture with nitrogen, phosphor and potassium as fertilizers in Maize plants (Zea mays L. ) and its soil under environmental condition of Egypt was studied. The tested herbicide was sprayed at recommended dose of $1.5 \mathrm{~L} /$ Fed on Maize plants . QuEChERA (catchers) method was used for extraction and clean - up of the samples. The treated Maize plants and soil were randomly sampled after 1,3,7,11,15 and 20 days after herbicide and mixture application. Samples were extracted, clean up and analyzed using Gas chromatography. The recovery percentages were $75 \%$ and $90 \%$ in soils and leaves, respectively .

The results revealed that the residues concentrations were $7.5,2.54$. $0.33,3.47 ; 4.62,4.13,4.73$ and $4.40 \mathrm{mg} / \mathrm{kg}$ in leaves of Maize plants and soil after 24h. in Basagran, Basagran $+\mathrm{N}$, Basagran $+\mathrm{P}$ and Basagran $+\mathrm{K}$ ,respectively. The herbicide residues on leaves of Maize plants were 5.21 to $2.04 ; 1.33$ to $0.69 ; 0.33$ to 0.04 and $3.37 \mathrm{mg} / \mathrm{kg}$ to ND from 3 days to 20 days in Basagran, Basagran $+\mathrm{N}$, Basagran $+\mathrm{P}$ and Basagran $+\mathrm{K}$ ,respectively. The corresponding residues on soil were 3.67 to ND; 4.13 to ND ; 4.73 to ND and 4.40 to ND mg / kg from 3 days to 20 days in Basagran, Basagran $+\mathrm{N}$, Basagran $+\mathrm{P}$ and Basagran $+\mathrm{K}$, respectively

The corresponding half - life values were $10.8,13.1,6,9$ and 2.66 days in Basagran, Basagran $+\mathrm{N}$, Basagran $+\mathrm{P}$ and Basagran $+\mathrm{K}$ ,respectively in leaves of Maize plants and 3.5, 3.4 , 3.0 , 2.5 days in soil samples. The residues on Maize plants were below the maximum residual level (MRL) value reported by the European Food Safety Authority (EFSA , 2013) of the herbicide and it was $0.2 \mathrm{mg} / \mathrm{Kg}$.
\end{abstract}

Key words: Determination, Bazagran, residues, Maize plants, soil

\section{INTRODUCTION}

Pesticides are widely used in various combinations and or different stages of cultivation and during post - harvest to protect crops against pests, (EL - Zaher et al. , 2011). Herbicides are used extensively in all farming systems. Herbicides, when applied to the field do not only control targeted weeds but also leave unwanted residues in plants and soil (Haney et al. ,2000; Derksen et al. ,2002). Herbicides have bad efficacy and have also poses mecum adverse effects on crops, ecology and the environment (Faheed and AbdELFattah, 2007) . On the other hand, the presence of residues in food 
was critical elements of overall population health and pesticides residues in food is of great importance in the evaluation of food quality( Gota et al. , 2003) .

Soil plays an important role in agro - ecosystem and the environment but information for analysis of herbicides residues in soil can be very difficult to come by. Contamination of soil and agriculture product by herbicides is an increasing environmental concern (Quyang et al., 2011). High performance liquid chromatography (HPLC) is commonly methods used to determine pesticides residues (Wahyu et al. , 2010).

Basagran belongs to the group of benzothiadiazole compounds which are used as herbicides .It is non - systemic selective contact herbicide used to control broad leaf weeds adsorbed mainly by the foliage with very little translocation but also adsorbed by the roots, with translocation acropetally in the xylem. The mode of action of Basagran is linked to the inhibition of the photosynthetic transport in the chloroplasts (photo system 2) which also causes growth inhibition (EFSA, 2011). Therefore this study aimed to determine the residues and dissipation rate of the herbicide Basagran on Maize leaves and soil at different intervals after application under field condition. Half life values in Maize plants and soil were determined.

\section{1 . Field experiment}

\section{MATERIALS AND METHODS}

This experiment was carried out at Zagazig district farms, Sharkia governorate during 2016 of Maize plants and soil . The mature plants were sprayed once with Basagran $48 \%$ AS using the recommended field rate $(1.5 \mathrm{~L} / \mathrm{Fed})$ to protect the plants from broad leaf weeds according to the Pest control Program of the Ministry of Agriculture (2014) and added nitrogen, phosphour and potassium as fertilizers with the aim to detect Basagran residues.

\section{2 . Sampling preparation for residue analysis}

Leaves samples of maize plants and soil were collected at random from treated and untreated plants after $1,3,7,11,15$ and 20 days post- treatment. Random samples were collected from three plots of each treatment for each plant and soil. During the first date of spray Basagran residues were determined chromatographically. The representative sample was cut into small pieces using knife and subjected to extraction and clean - up procedures for plants and digested for soil. 


\section{3 . Extraction and clean-up procedures.}

\subsection{Extraction}

Basagran residues were extracted from leaves of Maize plants and soil according to the method of QUECHERS (Lehotay et al., 2007; Raczkowski et al., 2011) . Weight of $10 \mathrm{~g}$ of the blended sample and were transferred to $50 \mathrm{ml}$ polypropylene centrifuge tube and add $10 \mathrm{ml}$ acetonitrile with $1 \%$ acetic acid . the sample was Shaken vigorously for $1 \mathrm{~min}$ and vortexed for $15 \mathrm{sec}$. Then add extract include : $6 \mathrm{~g}$ magnesium sulphate and $1.5 \mathrm{~g}$ anhydrous sodium acetate , $1 \mathrm{~g} \mathrm{Na} 3$ citrate dehydrate. Shake each tube directly after the salt addition shortly. Shake vigorously for $1 \mathrm{~min}$ and centrifuge for $5 \mathrm{~min}$ at $4000 \mathrm{U} /$ $\min$.

\section{2. Dispersive SPE clean - up processers}

Transfer $1 \mathrm{ml}$ aliquot of supernatant to a dispersive clean - up tube containing MgSO 4 , C18, PSA and GCB . Shake for 30 second and centrifuge for $5 \mathrm{~min}$ at $4000 \mathrm{U} / \mathrm{min}$.

\section{4 . Determination of herbicide residues .}

Residue determination of Basagran was carried out at pesticides center laboratory, Dokki, Giza with Gas chromatography. The chromatography was (Hewlett Packard GC model 6890 equipped with an Ni63 - electron capture detector. GC conditions : DB- 17 (J"W Scientific ) capillary column (30 m length * $0.32 \mathrm{~mm}$ internal diameter (i.d) * $0.25 \mathrm{u}$ film thickness ), carrier gas : N2 at a flow rate of $4 \mathrm{ml} /$ min. Injector and detector temperature were 300 and $320^{\circ} \mathrm{C}$. respectively. The initial column temperature was $160 \mathrm{C}$ for $2 \mathrm{~min}$, raised at $5 \mathrm{C} / \mathrm{min}$. and then held at $200 \mathrm{C}$ for $2 \mathrm{~min}$. The retention time of Basagran was about 6.673 min. Residues were estimated by comparison of peak area of standards with that of the unknown or spiked samples run under identical conditions.

\section{Recovery test}

Basagran was added to untreated control samples at three levels $(0.05,0.1$ and $1.0 \mathrm{mg} / \mathrm{kg})$. For method validation, control and fortified samples were analyzed under the same conditions. The average recoveries ranged from $75 \%$ and $90 \%$ in soils and leaves, respectively.

\section{Kinetic study}

The rate of degradation and half - life time were calculated according to (Ashour , 1976 ; Gomaa et al. ,1979) . The relationship between the logarithm of concentration of Basagran residues and time intervals were plotted. A straight line was fitted using excel trend line 
with intercept equal to logarithm of initial concentration and the slope of the line was calculated. Rate of degradation $(K)=2.303$ *slope

The half - life time calculated from the following equation :

T $0.5=0.693 / \mathrm{K}$

\section{RESULTS AND DISCUSSSION \\ 1 - Residues of Basagran and its mixture with fertilizers in Maize plant:}

Maize plants were sprayed once with Basagran at a concentration of $1.5 \mathrm{~L}$. per feddan and mixture with nitrogen, phosphor and potassium as fertilizers. Sample of plants were collected at random from treated plots after $1,3,7,11,15$, and 20 days of application . The residues of the applied herbicide were determined chemically by Gas chromatography apparatus after different intervals of application . The residue figures and dissipation percentages are presented in Table 1 and figures 1,2,3,4 .

Data show that the initial deposit ( 24h. after application ) of Basagran, Basagran $+\mathrm{N}$, Basagran $+\mathrm{P}$ and Basagran $+\mathrm{K}$ in Maize plants were $7.5,2,54,0.33$ and $3.37 \mathrm{ppm}$. , respectively. This amounts were decreased to $5.21,4.11,2.94,2.70,2.04 ; 1.33,1.21,1.08,1.00$, $0.69 ; 0.190,0.157,0.086,0.080,0.040 ; 1.65,1.39,1.13,0.04$ and ND ppm after $1,3,7,11,15$, and 20 days of spraying in Basagran , Basagran $+\mathrm{N}$, Basagran $+\mathrm{P}$ and Basagran $+\mathrm{K}$, respectively. Reductions in Basagran initial deposit reached 30.53 to $72.8 ; 47.63$ to $72.83 ; 42.2$ to 87.8 and 51.0 to $100 \%$ after $1,3,7$, 11,15 , and 20 days of application in Basagran $+\mathrm{N}$, Basagran $+\mathrm{P}$ and Basagran $+K$, respectively. Data presented in Table (1) and figures from 1 to 4 show that the residue half - life $\left(T_{1 / 2}\right)$ values were $10.8,13.1,6,9$ and 2.66 days in Basagran, Basagran $+\mathrm{N}$, Basagran $+\mathrm{P}$ and Basagran+ $\mathrm{K}$, respectively in leaves Maize plants , respectively, as determined by Gas chromatography . Maximum residue limits (MRL) of the herbicide Basagran was $0.2 \mathrm{mg} / \mathrm{Kg}$ (EFPA 2013).

Data indicate that addition phosphor and potassium as fertilizers for the herbicide reduced the amounts of residues in plants, while adding nitrogen increase amounts of residues, so it was necessary to add phosphor and potassium as fertilizers to herbicide during treatment .Such reduction may be due to rapidly metabolism of Basagran to derivatives of anthranlic acid, the principal metabolites being the 6 - hydroxyl bentazone and 8 - hydroxyl bentazone expressed as bentazone. Metabolism studies showed that 8 - hydroxyl bentazone is not found in most crops and might be disregarded from this residue definition which are conjugated to sugars forming glycosides . (EFSA. ,2013 ; Pesticides Manual V5 2010). 
Table 1. Residues (in ppm) of Basagran in Maize plants

\begin{tabular}{|c|c|c|c|c|c|c|c|c|}
\hline \multirow{2}{*}{$\begin{array}{c}\text { Days } \\
\text { after } \\
\text { treatme } \\
\text { nt }\end{array}$} & \multicolumn{2}{|c|}{ Bazagran } & \multicolumn{2}{|c|}{ Bazagran +nitrogen } & \multicolumn{2}{|c|}{ Bazagran +phosphour } & \multicolumn{2}{|c|}{ Bazagran +postasium } \\
\hline & Residues & $\begin{array}{c}\% \\
\text { Dissipation } \\
\end{array}$ & $\begin{array}{l}\text { Residu } \\
\text { es }\end{array}$ & $\begin{array}{c}\% \\
\text { Dissipati } \\
\text { on }^{\star}\end{array}$ & $\begin{array}{l}\text { Residu } \\
\text { es }\end{array}$ & $\begin{array}{c}\% \\
\text { Dissipatio } \\
\mathbf{n}^{\star}\end{array}$ & $\begin{array}{l}\text { Residu } \\
\text { es }\end{array}$ & $\begin{array}{c}\% \\
\begin{array}{c}\text { Dissipatio } \\
\mathrm{n}^{\star}\end{array} \\
\end{array}$ \\
\hline 1 & 7.5 & ---------- & 2.54 & ----------- & 0.33 & ----------- & 3.37 & $-\cdots-----$ \\
\hline 3 & 5.21 & 30.53 & 1.33 & 47.63 & 0.190 & 52.4 & 1.65 & 51.00 \\
\hline 7 & 4.11 & 45.20 & 1.21 & 52.36 & 0.157 & 42.2 & 1.39 & 58.80 \\
\hline 11 & 2.94 & 60.80 & 1.08 & 57.48 & 0.086 & 73.9 & 1.13 & 66.40 \\
\hline 15 & 2.70 & 64.00 & 1.00 & 60.62 & 0.080 & 75.75 & 0.04 & 98.80 \\
\hline 20 & 2.04 & 72.80 & 0.69 & 72.83 & 0.040 & 87.8 & ND & 100 \\
\hline
\end{tabular}

* Based on the actual remainder of the residues

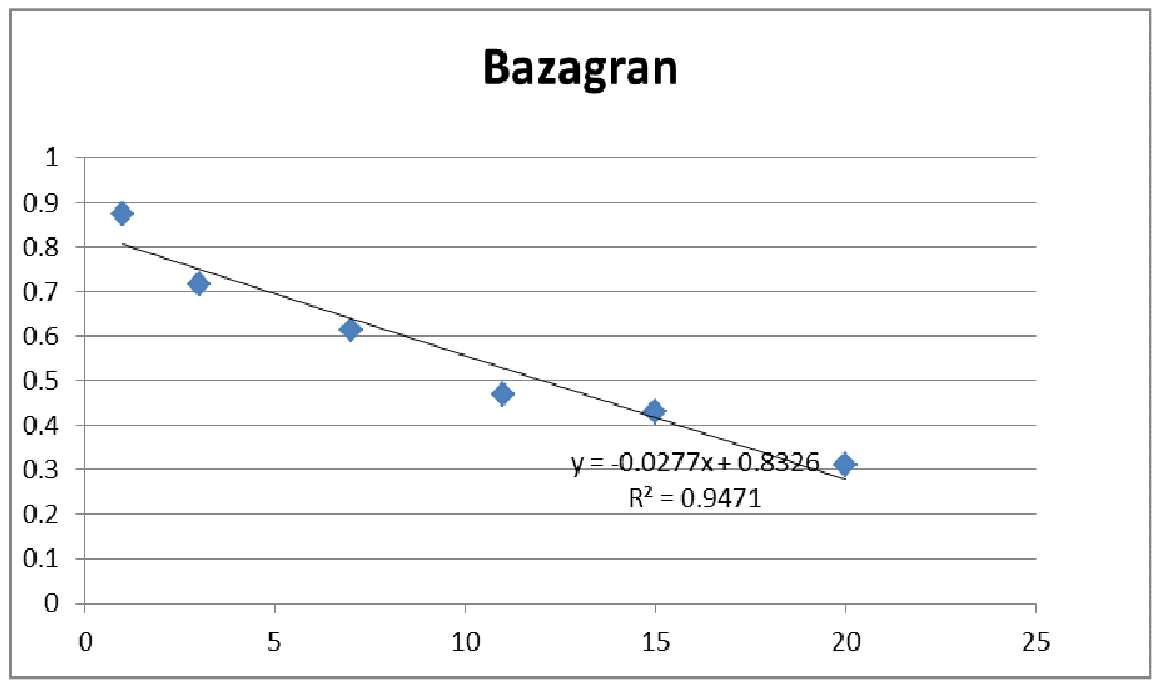

Fig 1. Regression lines of logarithm Basagran residues concentration versus days after application on Maize plants

These results are in harmony with results obtained by (Shobha Sondhia , 2014 ; xiaoxia Feng et al. , 2016 ; Howard Deer , 1999 ). 2 - Residues of Basagran and its mixture in Maize soil .

Sample of soil were collected at random from treated plots after $1,3,7,11,15$, and 20 days of application. The residues of the applied herbicide were determined chemically by Gas chromatography apparatus after different intervals of application. The residue figures and dissipation percentages are presented in Table 2. and figures 5 to 8 .

Data show that the initial deposit ( $24 \mathrm{~h}$. after application ) of Basagran, Basagran $+\mathrm{N}$, Basagran $+\mathrm{P}$ and Basagran $+\mathrm{K}$ in Maize soil were $4.62,4.13,4.73$ and $4.40 \mathrm{ppm}$. This amounts were decreased to $3.67,2.11,0.71,0.31, \mathrm{ND} ; 2.43,2.44,0.55,0.24$, ND ; $3.33,2.07,0.49,0.21, N D ; 3.001 .99,0.32,0.11$ and ND ppm after $1,3,7,11,15$, and 20 days of spraying in Basagran , Basagran $+\mathrm{N}$, Basagran $+\mathrm{P}$ and Basagran $+\mathrm{K}$, respectively. 
Reductions in Basagran initial deposit reached 20.56 to $100 ; 41.16$ to $100 ; 29.59$ to 100 and 31.81 to $100 \%$ after $1,3,7,11,15$, and 20 days of application in Basagran $+\mathrm{N}$, Basagran $+\mathrm{P}$ and Basagran $+\mathrm{K}$ , respectively. Data presented in Table (2) and figures 5 to 8 , the calculated half - values (RL50) of Basagran , Basagran $+N$, Basagran $+\mathrm{P}$ and Basagran + $\mathrm{K}$ were 3.5, 3.4 , 3.0 , 2,5 days, respectively .

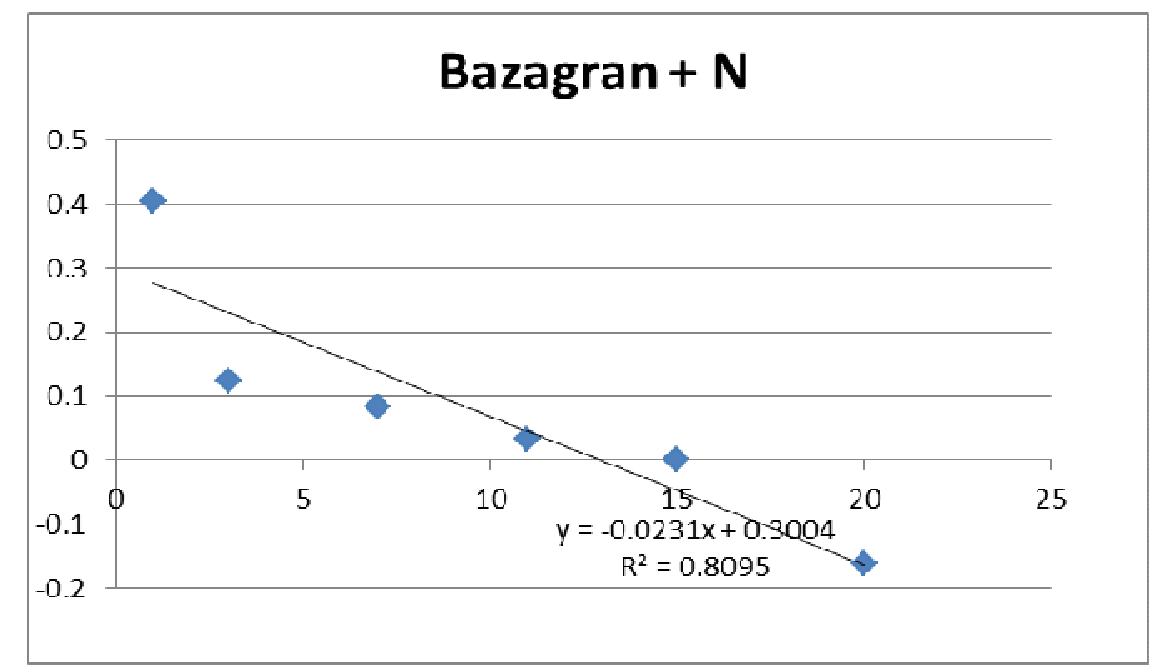

Fig 2. Regression lines of logarithm Basagran $+\mathrm{N}$ residues concentrations versus days after application on Maize plants

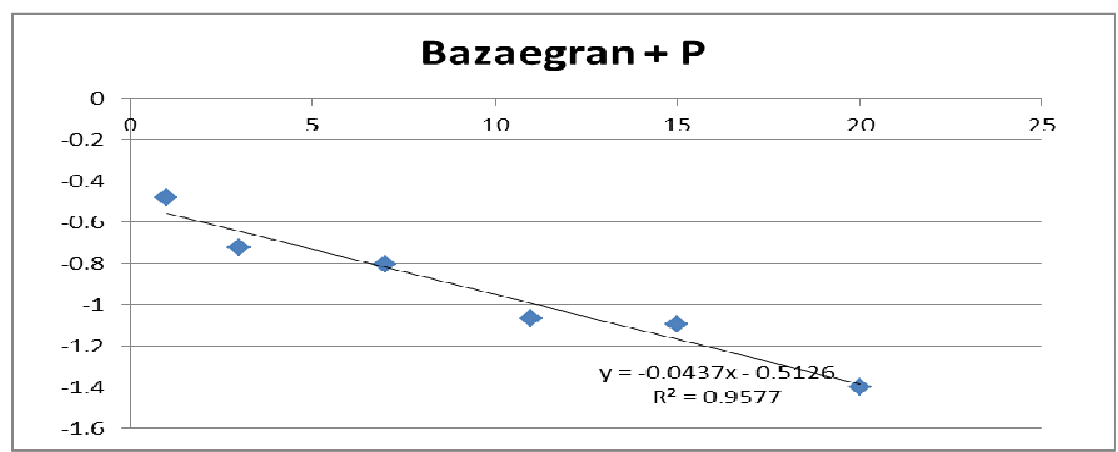

Fig 3. Regression lines of logarithm Basagran $+P$ residues concentrations versus days after application on Maize plants 


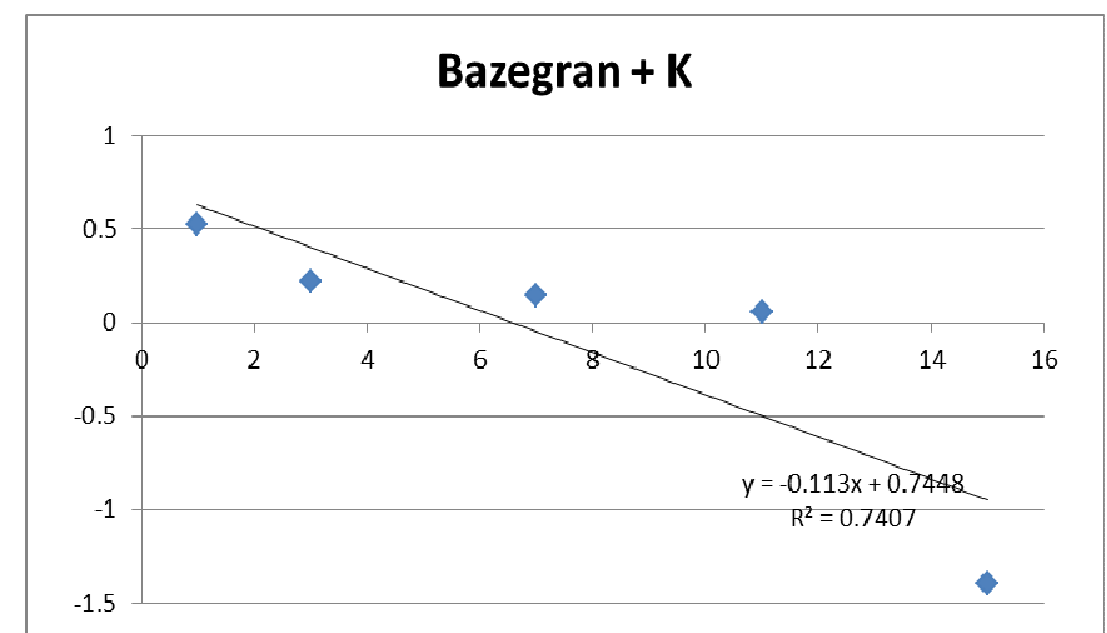

Fig 4. Regression lines of logarithm Basagran $+K$ residues concentrations versus days after application on Maize plants

Table 2. Residues (in ppm) of Basagran in Maize soil

\begin{tabular}{|c|c|c|c|c|c|c|c|c|}
\hline \multirow{2}{*}{$\begin{array}{c}\text { Days } \\
\text { after } \\
\text { treatment }\end{array}$} & \multicolumn{2}{|c|}{ Bazagran } & \multicolumn{2}{|c|}{ Bazagran +nitrogen } & \multicolumn{2}{|c|}{ Bazagran +phosphour } & \multicolumn{2}{|c|}{ Bazagran +postasium } \\
\hline & Residues & $\begin{array}{c}\% \\
\text { Dissipation* }\end{array}$ & Residues & $\begin{array}{c}\% \\
\text { Dissipation }\end{array}$ & Residues & $\begin{array}{c}\% \\
\text { Dissipation }\end{array}$ & Residues & $\begin{array}{c}\% \\
\text { Dissipation* }\end{array}$ \\
\hline 1 & 4.62 & & 4.13 & & 4.73 & & 4.40 & \\
\hline 3 & 3.67 & 20.56 & 2.43 & 41.16 & 3.33 & 29.59 & 3.00 & 31.81 \\
\hline 7 & 2.11 & 54.32 & 2.44 & 40.92 & 2,07 & 56.23 & 1.99 & 54.77 \\
\hline 11 & 0.71 & 84.63 & 0.50 & 87.89 & 0.49 & 89.64 & 0.32 & 92.72 \\
\hline 15 & 0.31 & 93.29 & 0.24 & 44.18 & 0.21 & 95.56 & 0.11 & 97.5 \\
\hline 20 & ND & 100 & $\mathrm{ND}$ & 100 & ND & 100 & ND & 100 \\
\hline
\end{tabular}

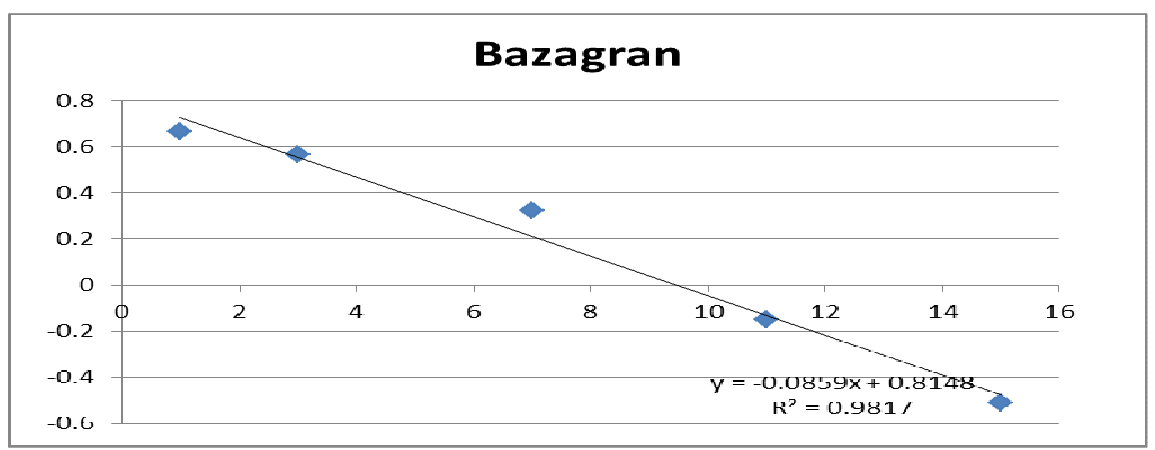

Fig 5: Regression lines of logarithm Basagran residues concentration versus days after application on soil 


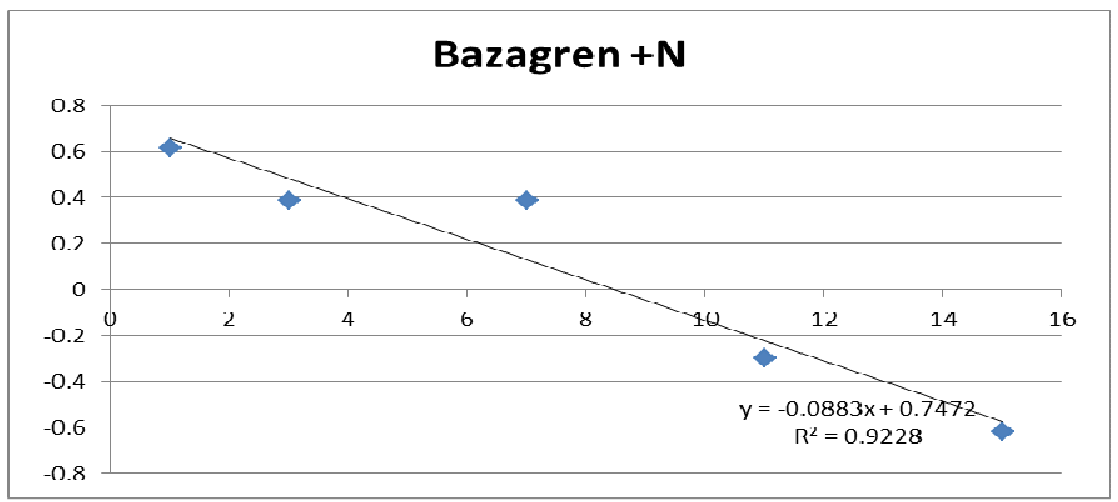

Fig 6. Regression lines of logarithm Basagran $+\mathrm{N}$ residues concentrations versus days after application on soil

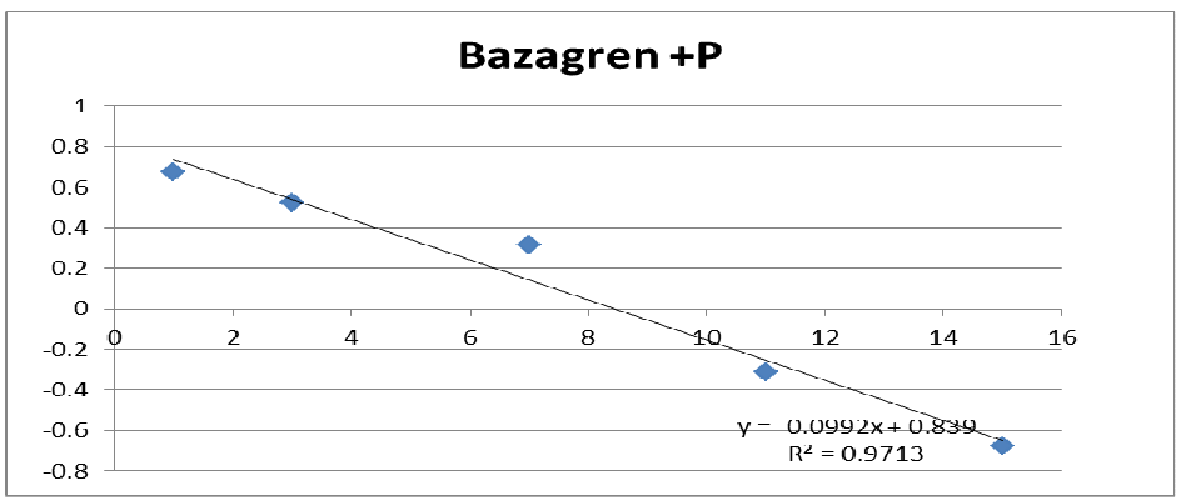

Fig 7. Regression lines of logarithm Basagran $+P$ residues concentrations versus days after application on soil

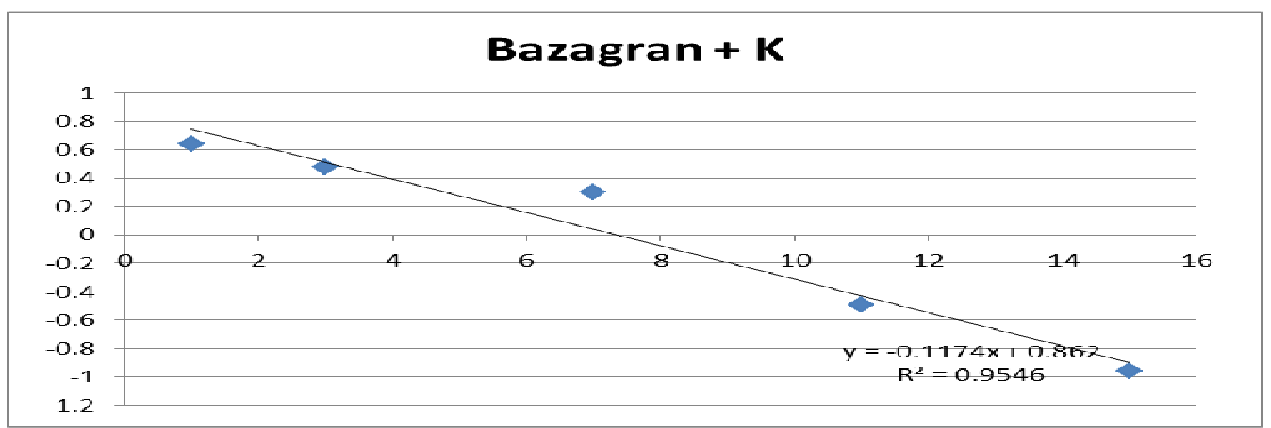

Fig 8. Regression lines of logarithm Basagran $+K$ residues concentrations versus days after application on soil 
Herbicide residues in crop produce above the safe level can cause health hazards to men and animals. Fate of herbicide in soil depends on number of processes such as volatilization, leaching, runoff and degradation by microbes, chemical processes and photodecomposition.

\section{References}

Ashour , M-B.A. (1976) . Residual effect of certain soil pesticides on some field crops. M.Sc. Thesis, Fac. Agric. ,Zagazig Univ. Egypt.

Derksen , D.A. ; Anderson , R.L. ; Black Show R.E. ; Maxwell , B. (2002). Weed dynamic and management strategies for cropping systems in the Northern Great plains . J. of Agron. $94: 174-$ 185.

European Food Safety Authority (EFSA), (2011). Conclusion on the peer review of the pesticide risk assessment of the active substance bentazone. EFSA Journal , $10(7): 2822$.

European Food Safety Authority (EFSA ), (2013) .Reasoned opinion on the modification of the existing MRLS for bentazone in legume and vegetables. Journal , 9 (5) : 2188,29 PP.

Faheed , F.A. and Abd - EL Fattah .(2007). Alteration in growth and physiological activities in Chlorella vulgaris under the effect of photosynthetic inhibitor diuron . Int . J. Agric Biol. 9 : $631-643$

Gomaa , E.A. ; M.H. Belal and M-B.A. Ashour. (1979 ). Influence Temik on herbicide persistence in cultivated cotton field soil under field condition . Bulletin of Environ. Contamination and Toxicol . (22) : $717-725$.

Gota , T. ; Y. Ito ; H. Oka ; H. Saito Matsumoto and H. Nakazwa . (2003) . Sample and rapid determination of $\mathbf{N}$ - methyl carbamate pesticides in citrus by electrospray ionization tandem mass spectrometry . Aralytica chimica Acta . (4) : 201 - 209.

Haney , R.L. ; Sanseman , S.A. ; Hons , F.M. and Zuberer , D.A. (2000) . Effect of glyphosate on soil microbial activity and biomass . Weed science . (48) : $89-93$.

Howard M. Deer . (1999). Pesticide adsorption and half - life . SCS/ ARS / CES . Pesticide properties database for environmental decision.

Lehotay , S.L. (2007). Determination of pesticide residues in foods by acetonitrile extraction and partitioning with magnesium sulfate : collaborative study . J. AOAC Int. 90 (2) : 485 - 520.

Quyang , Y. ; Mansell , R.S. and N kedi - Kizza , P. ( 2011). A simple high performance liquid chromatography method for analyzed paraquat in soil soluilion samples . J. Environ . Qual. (33) : 406 $-408$. 
Raczkowski , M. ; A. Holodynska ; A. Nowacka and B. Gnusowski . (2011) . Application of the QuEchERS method for determination of pesticide residues in tomato samples using GC - NPD / ECD . Progress in plant . 51 (2) : 727 - 731.

Shobha Sondhia . (2014). Herbicides residues in soil, water, plants and non - targeted organisms human health implications :an Indian perspective .Indian journal of weed science .46 (1) : 66 85.

Tahany .R.Abd EL - Zaher , I.N.Naser and Hend A.Mohamed (2011) . Bhavior of some pesticides residue in and on tomato and kidney beans fruits grown in open field. American - Eurasian journal of toxicological science $3(3): 213-218$.

Wahyu , w. ; Rosli , B.M. ; Dzlkhiflio , Numasiroh M.Z. ; Adam , B.P. and Yahya, A. (2010) . Comparative impact of a single application of selected broad spectrum herbicides on ecological componens of ailpaim plantation. Afr. J. Agric. Res. 5 (16) : 2097 - 2102.

Xiaoxiao Feng, Jianliei Yu, Lixiang Pan, Guochun Song and Hongyan Zhang . (2016). Dissipation and residues of dichlorop - $p$ and bentazone in wheet - field ecosystem . International journal of environmental research and public health . (2-14).

تقدير متبقيات مبيد الحشائش بازجران فى نبات الذره والتربه

$$
\text { قسم وقايه النبات ـ كليه الزراعه ـ ـ جامعه الزقازيق محمد السيا سالم }
$$

تم دراسه تاثير متبقيات مبيد البنتازون ( بازجران 48 \% \% ) بمفرده و وعند خلطه بالسماد

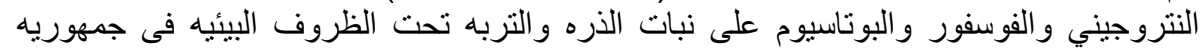

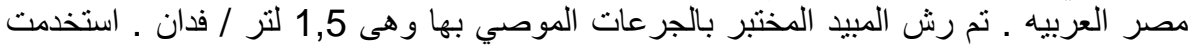

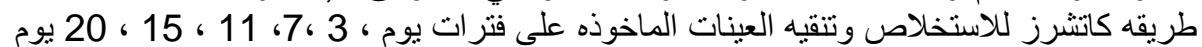

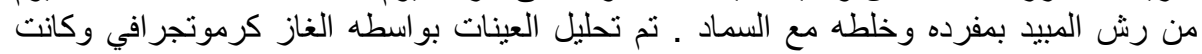

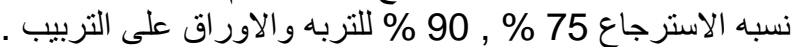

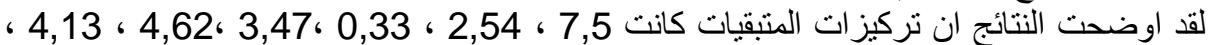

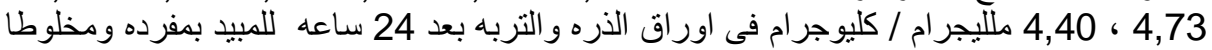

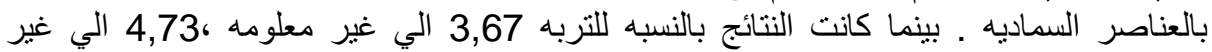

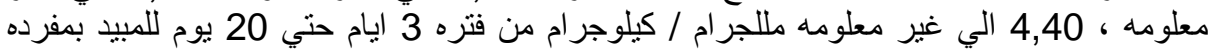
ومحلوطا بالعناصر الليماديه

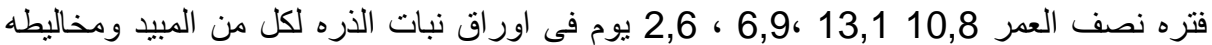

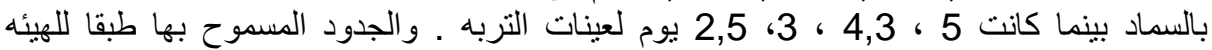

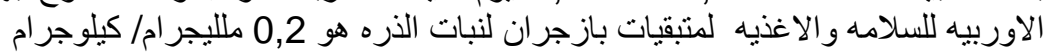

